\title{
Bioprospek
}

https://fmipa.unmul.ac.id/jurnal/index/Bioprospek

\section{ETNOBOTANI BUAH EDIBEL PADA MASYARAKAT DAYAK TAHOL DI KABUPATEN MALINAU, KALIMANTAN UTARA}

\author{
DT. Ardiansyah ${ }^{1}$, Medi Hendra ${ }^{2}$, Dwi Susanto ${ }^{3}$ \\ ${ }^{1,2,3}$ Jurusan Biologi, Fakultas MIPA, Universitas Mulawarman
}

\section{INFO ARTIKEL}

Terkirim 10 Juni 2018

Diterima 23 Juli 2018

Online 18 Semptember 2018

Kata kunci.

Etnobotany

Edible fruits

Dayak Tahol

\begin{abstract}
A B S T RA K
Forest has been considered as one of natural resources that could brought benefits for Dayak community based on their ecological and economical values. Edible fruits are annual plant type that could grow fruits and can be consumed. This study was held to obtain data, what type of plant that is utilized by Dayak Tahol community in their daily lives and how they utilize the edible fruits from Malinau district. This study was conducted by using explorative survey method, which is divided into two steps: first, the edible fruits inventory which is familiar by local people; second, observation at the local community and this method is supported by approach and sampling technique. This result showed that the total known edible fruits plant was about fifty two genus obtained from twenty five families and 2.207 individual species in total, moreover Shanoon-Winner diversity index $\left(\mathrm{H}^{\prime}=3.49\right)$ can be grouped in high diversity ( $\left.\mathrm{H}^{\prime}>3\right)$.
\end{abstract}

\section{Pendahuluan}

Kalimantan Utara adalah salah satu provinsi di Indonesia yang terletak dibagian utara Pulau Kalimantan dan merupakan provinsi termuda di Indonesia. Provinsi ini memiliki keanekaragaman hayati dan sumber daya alam yang sangat tinggi. Hal ini didukung dengan daerah yang dikelilingi oleh area hutan hujan tropis yang luas, memiliki luas hutan sebesar 7.855.168 ha yang berpotensi menghasilkan kayu alam dan berbagai produk hutan lainnya. Hutan merupakan basis utama dari kehidupan, sosial, ekonomi, budaya, dan politik kelompok etnik Dayak (BPS, 2016).

\section{Korespondensi:}

bioprospek@fmipa.unmul.ac.id

Hutan merupakan salah satu sumber daya alam yang memberi manfaat bagi masyarakat Dayak baik secara ekologis maupun ekonomis. Hutan kaya akan buahbuahan yang dihasilkan oleh tanaman yang tumbuh secara alami. Buah-buahan ini menjadi sumber makanan bagi hewanhewan yang hidup di hutan, namun tidak menutup kemungkinan bagi masyarakat 
dayak yang tinggal disekitar hutan untuk memanfaatkannya. Pemanfaatan buah edibel ini telah lama dilakukan oleh masyarakat Dayak yang bertempat tinggal di sekitar hutan, sehingga memungkinkan terdapat beberapa buah edible yang pemanfaatannya hanya diketahui oleh masyarakat dayak setempat (Usat, 2016).

Menurut Verheij dan Coronel (1991) buah edibel (edible fruits) adalah jenis tumbuhan tahunan yang menghasilkan buah dapat dimakan. Buah tersebut baik sebagai fungsi utama atau hanya sampingan dan yang dimakan segar secara langsung ataupun diproses terlebih dulu serta yang lazim dikonsumsi masyarakat lokal. Namun beberapa jenis yang buahnya tidak lazim dimakan tetapi berasal dari marga (genus) yang umum dikenal sebagai kelompok buah-buahan dimasukkan dalam batasan ini. Hal ini mengingat potensi sumber daya genetik (plasma nuftah) yang terkandung dalam setiap jenisnya.

Menurut Afrianti (2007), mata pencaharian suku Dayak selalu ada hubungannya dengan hutan. Suku Dayak merupakan suku terbesar yang menempati daerah-daerah pedalaman Kalimantan Utara dan bergantung pada sumber daya alam terutama dibidang pertanian. Kabupaten Malinau dihuni oleh beberapa suku dayak yang beragam yaitu suku dayak Kenyah, Lun Bawang/Lun dayeh, Tidung, Punan, Merap, Abbay, Burusu, Murut/Tahol dan Tagal (BPS, 2016).

\section{Metode Penelitian}

Waktu dan Tempat Penelitian

Penelitian ini dilaksanakan mulai dari bulan Januari sampai Maret 2018 di Desa Putat, Salap, Seruyung dan Belayan, Kecamatan Malinau Utara, Kalimantan Utara. Kemudian identifikasi spesimen dan pembuatan herbarium akan dilakukan di Laboratorium Ekologi dan Sistematika Tumbuhan, Fakultas Matematika Dan Ilmu Pengetahuan Alam, Universitas Mulawarman, Samarinda.

Alat dan Bahan
Alat yang akan digunakan pada penelitian ini adalah gunting tanaman, kamera, alat perekam suara, GPS, papan tripleks, jarum, alat tulis lengkap, buku determinasi/identifikasi, alat penyemprot dan oven. Sedangkan bahan yang digunakan kertas karton, kertas pelastik untuk pembuatan herbarium, kertas label untuk memberi nama spesimen, kertas koran, kantong pelastik, alkohol 70\%, benang wol, kardus, dan spesimen tumbuhan buah edibel, objek penelitian ini adalah masyarakat Suku Dayak Tahol di Kabupaten Malinau, Kalimantan Utara.

\section{Metode Penelitian}

Penelitian menggunakan metode survei eksploratif dengan modifikasi aneka metode etnosains yang dipakai para pakar. Metode ini mencangkup: 1. Inventarisasi jenis tumbuhan buah edibel yang diketahui masyarakat meliputi nama lokal dan ilmiahnya serta manfaatnya dan 2 . Observasi di lingkungan masyarakat yaitu mempelajari keberadaan dan upaya konservasi yang telah dilakukan mereka. Metode ini didukung oleh pendekatan dan teknik pengambilan sebagai berikut:

\section{Pendekatan}

Pendekatan ini menggunakan penilaian desa partisipatif (participatory rural appraisal, PRA). Pendekatan ini meliputi: 1. Wawancara semiterstruktur dan terjadwal untuk iventarisasi pengetahuan lokal; 2 . transect-walks sistematis dengan masyarakat sebagai pemandu dan informan kunci; dan 3. Persahabatan erat dengan masyarakat ikut-aktif dalam aktivitas mereka baik harian maupun khusus.

Teknik Sampling dan Pengumpulan Informasi

a. Sampling atau pengambilan contoh dengan: 1. Teknik purposive-sampling pada masyarakat untuk informan kunci membagi tiga kelompok (tokoh adat, kepala desa dan masyarakat biasa); 2. Informan kunci diambil 10\% komunitas; 
dan 3. Membagi kelompok informan berdasar Jender dan tingkat usia (muda, 16-25; dewasa 26-55; dan tua 56-70 tahun).

b. Pengumpulan informasi dilakukan dengan: 1. Catatan dan rekaman wawancara; 2. Lembar isian (kuesioner) singkat/sederhana diakhir proses 3 . Lembar isian dan catatan observasi dan transect-walks 4. Catatan dan informasi terkait (cerita, studi kasus dan temuan warga).

Prosedur Kerja

a. Wawancara

Kegiatan wawancara ini akan menggunakan teknik wawancara semi struktural yang berpedoman pada daftar pertanyaan seperti: nama lokal tanaman, bagian yang dimanfaatkan, manfaatnya, cara pemanfaatannya, status tanaman (liar atau budidaya) dan lainnya (Supriati \& Kasrina, 2003).

\section{b. Survei Lapangan}

Kegiatan survei lapangan ini bertujuan untuk mendapatkan data awal penelitian. Survei ini dilakukan dengan melihat kondisi tempat tumbuh spesies tumbuhan buahbuahan edibel, kondisi umum lokasi dilapangan dan kondisi masyarakat Dayak Tahol.

\section{c. Inventarisasi Lapangan}

Kegiatan inventarisasi lapangan ini membuktikan fakta keberadaan tumbuhan di lapangan yaitu dengan pengambilan gambar dan pengambilan sampel tumbuhan buahbuahan edibel serta mencatat kordinat lokasi pengambilan sampel.

\section{Hasil dan Pembahasan}

Berdasarkan hasil penelitian yang dilakukan pada masyarakat Dayak Tahol di Kabupaten Malinau dengan jumlah informan sebanyak 50 orang yang terdiri dari masyarakat (Muda), masyarakat (Tua), masyarakat (Dewasa), ketua adat (katuo adat), tetua warga (matuo warga) dan kepala desa (katuo kampung).

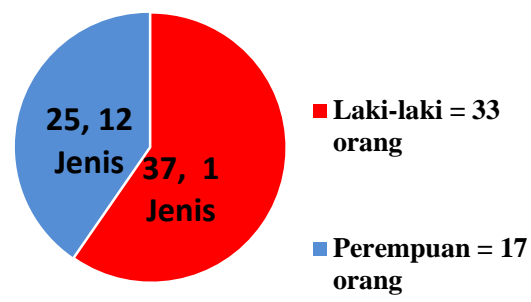

Gambar 4.1 Jumlah Jenis Tumbuhan Katagori Gender

Hasil penelitian menunjukkan bahwa katagori gender atau jenis kelamin merupakan faktor yang harus diperhatikan untuk mempelajari pengetahuan masyarakat tentang tumbuhan buah edibel. Pada gambar 4.1 terlihat bahwa jumlah rata-rata jenis tumbuhan yang diketahui oleh kelompok masyarakat kaum laki-laki (L) sebanyak 37.1 jenis dan kaum perempuan (P) sebanyak 25.12 jenis. Jumlah rata-rata pengetahuan tentang buah edibel dari kaum laki-laki (L) lebih banyak dibandingkan kaum perempuan (P) disebabkan pengalaman dan aktivitas lelaki relatif lebih banyak dan lebih lama berada di dalam hutan atau lebih luas jelajahnya dibandingkan kaum perempuan.

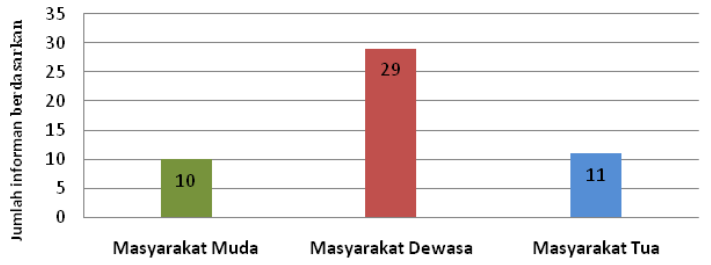

Gambar 4.2 Jumlah Informan Berdasarkan Umur 
Pada Gambar 4.2 di atas. Terlihat bahwa jumlah informan berdasarkan umur dalam masyarakat sangat bervariasi. Pembagian jumlah informan berdasarkan umur meliputi masyarakat (Muda) dengan batasan umur 16-25 tahun dengan jumlah informan 10 orang, masyarakat (Dewasa) dengan batasan umur 26-55 tahun dengan jumlah informan 29 orang, masyarakat (Tua) dengan batasan umur 56-73 tahun dengan jumlah informan 11 orang. Dimana jumlah informan masyarakat (Dewasa) lebih banyak dibandingkan dengan kedua informan masyarakat (Muda) dan masyarakat (Tua).

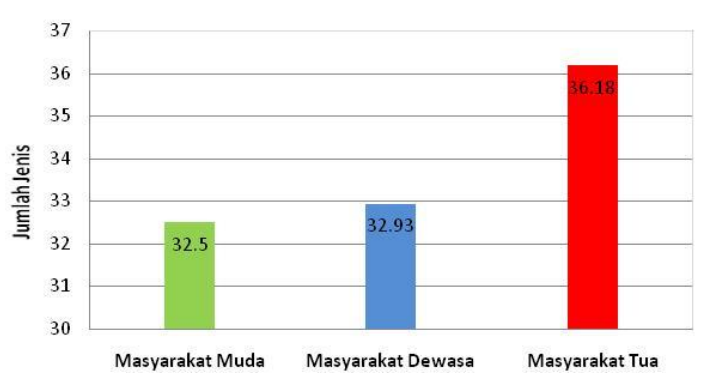

Gambar 4.3 Jumlah jenis tumbuhan yang diketahui oleh informan berdasarkan umur

Pengenalan buah edibel pada kuesioner P2 paling banyak diketahui oleh Masyarakat (Tua) yang memiliki pengetahuan tumbuhan buah edibel dengan nilai rata-rata sebanyak 36,18 jenis (Gambar 4.3). Karena masyarakat (Tua) ini merupakan orang yang biasa kehutan, aktif dalam berladang. Sementara itu masyarakat (Dewasa) nilai rata-rata jumlah jenis tumbuhan buah edibel yang diketahuinya sebanyak 32,93 jenis. Hal ini menunjukkan masyarakat (Dewasa) sering melakukan aktivitas berladang, berkebun dan berburu di hutan. Sehingga untuk pengetahuan buah edibel nya pada masyarakat (Dewasa) cukup baik. Hal demikian juga diungkapkan oleh Ayu (2012) pada masyarakat suku Kenyah di Long Alango, Kecamatan Bahau Hulu. Kearifan tradisional merupakan semua bentuk pengetahuan, keyakinan, pemahaman, atau wawasan, serta adat kebiasaan atau etika yang menuntun perilaku manusia di dalam komunitas ekologis (Keraf 2005).
Jumlah jenis tumbuhan buah edibel yang diketahui oleh masyarakat (Muda) dengan nilai rata-rata 32,5 jenis. Dari ketiga katagori ini masyarakat (Muda) paling sedikit mengetahui jenis tumbuhan buah edibel tersebut. Hal ini disebabkan masyarakat (Muda) jarang sekali beraktivitas di dalam hutan sebagian masyarakat (Muda) tidak begitu banyak mengenal jenis-jenis buah yang ada di dalam hutan tersebut. Sehingga untuk pengetahuan jenis buah edibelnya tidak begitu banyak.

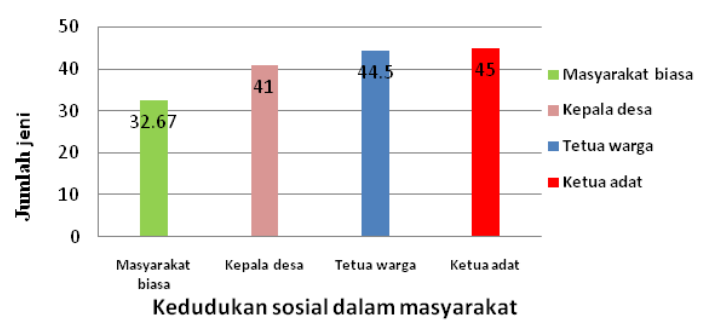

Gambar 4.4 Jumlah jenis tumbuhan yang diketahui oleh kedudukan sosial dalam masyarakat

Ada empat kelompok kedudukan sosial dalam masyarakat pada (Gambar 4.4) di atas. Terlihat bahwa pengetahuan jumlah jenis buah edibel berdasarkan pengelompokan kedudukan sosial dalam masyarakat sangat bervariasi. Pengelompokan tersebut meliputi: masyarakat biasa, kepala desa, tetua warga dan ketua adat.

Pengenalan buah edibel pada kuesioner P2 paling sedikit diketahui oleh masyarakat biasa dengan nilai rata-rata 32.67 jenis. Hal ini disebabkan sebagian masyarakat biasa tidak begitu banyak beraktivitas di dalam hutan seperti berburu dan meramu, sehingga untuk pengetahuan buah edibelnya tidak begitu banyak. Hanya saja masyarakat biasa lebih banyak beraktivitas di ladang dan berkebun seperti menanam padi, singkong dan sayuran. Walaupun ada salah satu masyarakat biasa memiliki pengetahuan lebih, merupakan masyarakat yang memiliki aktivitas di dalam hutan cukup banyak seperti berburu dan meramu, sehingga 
pengetahuan tentang buah edibelnya cukup baik.

Kepala Desa memiliki pengetahuan tumbuhan buah edibel dengan nilai rata-rata sebanyak 41 jenis. Orang yang dipilih sebagai kepala desa biasanya juga memiliki pengetahuan yang luas termasuk pengenalan tentang tumbuhan. Sedangkan Tetua warga memiliki pengetahuan tumbuhan buah edibel sebanyak 44.5 jenis lebih banyak dari kepala desa, dimana tetua warga ini merupakan orang yang dulunya banyak beraktivitas di dalam hutan dan juga banyak mengetahui tentang hutan adat yang ada di kampung mereka tersebut. Sehingga untuk pengenalan buah edibel tetua warga memiliki pengetahuan yang cukup baik.

Pengenalan buah edibel pada kuesioner P2 paling banyak diketahui oleh ketua adat dengan nilai rata-rata sebanyak 45 jenis tumbuhan buah (Gambar 4.4). Hal ini mungkin disebabkan ketua adat biasanya dipilih dari orang yang memang pengetahuannya cukup luas. Disamping itu ketua adat merupakan masyarakat yang paling banyak berhubungan dengan tradisi adat dan merupakan masyarakat yang banyak mengetahui tentang hutan adat di kampung tersebut. Menurut Fakhrurrozi (2001), seorang kepala adat Dayak adalah anggota masyarakat khusus yang paling banyak berhubungan dengan tradisi adatistiadat, sekaligus paling berkepentingan dalam hal pewarisan tradisi tersebut terutama pengetahuan tradisionalnya (contohnya dalam hal pengobatan). Selain itu merekalah yang paling sering menjadi kelompok representatif komunitas adat jika terjadi kontak dalam masyarakat, baik ke luar maupun ke dalam lingkungannya.

Berdasarkan data hasil penelitian ditemukan 52 spesies tumbuhan buah edibel dengan total perjumpaan 2.207 individu. Tingkat keanekaragaman $(3,49)$ maka dari hasil tersebut tergolong dalam keanekaragaman tinggi H'> 3. Buah edibel secara keseluruhan yang ditemukan berjumlah 52 spesies dengan jumlah individu 2.207 individu dengan indeks keanekaragaman
3,49 Jumlah spesies berpengaruh pada indeks keanekaragaman yang diperoleh. Berdasarkan data hasil penelitian yang diperoleh menunjukkan semakin banyak spesies buah yang ditemukan maka semakin tinggi indeks keanekaragamannya. 
Tabel 4.1 Keanekaragaman Jenis Buah Edibel Pada Masyarakat Dayak Tahol

\begin{tabular}{|c|c|c|c|c|c|}
\hline No & Nama Ilmiah & $\begin{array}{l}\text { Jumlah } \\
\text { individu }\end{array}$ & $\mathbf{P i}$ & Ln Pi & $\mathbf{H}^{\prime}$ \\
\hline 1 & Artocarpus integer Merr. & 121 & 0.054826 & -2.9036 & -0.15919 \\
\hline 2 & Artocarpus odoratissimus Blanco. & 67 & 0.030358 & -3.4947 & -0.10609 \\
\hline 3 & Lansium domecticum Correa. & 129 & 0.05845 & -2.83958 & -0.16597 \\
\hline 4 & Nephelium lappaceum $\mathrm{L}$. & 102 & 0.046217 & -3.07442 & -0.14209 \\
\hline 5 & Mangifera indica $\mathrm{L}$. & 52 & 0.023561 & -3.74815 & -0.08831 \\
\hline 6 & Baccaurea lanceolata Miq. & 37 & 0.016765 & -4.08847 & -0.06854 \\
\hline 7 & Willughbeia angustifolia Miq. & 2 & 0.000906 & -7.00624 & -0.00635 \\
\hline 8 & Bccaurea macrocarpa Miq. & 13 & 0.00589 & -5.13444 & -0.03024 \\
\hline 9 & Mangifera pajang Kostermans. & 4 & 0.001812 & -6.3131 & -0.01144 \\
\hline 10 & Mangifera torquenda Kostermans. & 6 & 0.002719 & -5.90763 & -0.01606 \\
\hline 11 & Durio lowianus Scort \& King. & 115 & 0.052107 & -2.95446 & -0.15395 \\
\hline 12 & Durio kutejensis Hassk. & 109 & 0.049388 & -3.00804 & -0.14856 \\
\hline 13 & Musa borneensis Beccari. & 112 & 0.050748 & -2.98089 & -0.15127 \\
\hline 14 & Hornstedtia havilandii K. Schum & 67 & 0.030358 & -3.4947 & -0.10609 \\
\hline 15 & Theobroma cacao L. & 50 & 0.022655 & -3.78737 & -0.0858 \\
\hline 16 & Artocarpus heteropyllus Lam. & 32 & 0.014499 & -4.23365 & -0.06139 \\
\hline 17 & Nephelium ramboutan-ake (Labill.) Leenh. & 5 & 0.002266 & -6.08995 & -0.0138 \\
\hline 18 & Nephelium cuspidatum Blume. & 10 & 0.004531 & -5.3968 & -0.02445 \\
\hline 19 & Pangium edule Reinw. & 7 & 0.003172 & -5.75348 & -0.01825 \\
\hline 20 & Eleiodoxa confferta (Griff.) Burret & 22 & 0.009968 & -4.60835 & -0.04594 \\
\hline 21 & Solanum torvum $\mathrm{Sw}$. & 16 & 0.00725 & -4.9268 & -0.03572 \\
\hline 22 & Durio oxleyanus Griff. & 13 & 0.00589 & -5.13444 & -0.03024 \\
\hline 23 & Baccaurea angulata Merr. & 3 & 0.001359 & -6.60078 & -0.00897 \\
\hline 24 & Durio Graveolens Becc. & 15 & 0.006797 & -4.99134 & -0.03392 \\
\hline 25 & Sarcotheca monophylla Hallier. & 25 & 0.011328 & -4.48051 & -0.05075 \\
\hline 26 & Artocarpus ridigus Blume. & 3 & 0.001359 & -6.60078 & -0.00897 \\
\hline 27 & Curculigo latifolia Gaertn. & 132 & 0.05981 & -2.81659 & -0.16846 \\
\hline 28 & Ficus uncinata (King) Becc. & 34 & 0.015406 & -4.17303 & -0.06429 \\
\hline 29 & Ficus sp. & 56 & 0.025374 & -3.67404 & -0.09322 \\
\hline 30 & Flacourtia rukam Zoll \& Mor. & 19 & 0.008609 & -4.75495 & -0.04094 \\
\hline 31 & Dimocarpus longan Lour. & 11 & 0.004984 & -5.30149 & -0.02642 \\
\hline 32 & Averrhoa blimbi $\mathrm{L}$. & 7 & 0.003172 & -5.75348 & -0.01825 \\
\hline 33 & Ficus racemosa L. & 88 & 0.039873 & -3.22205 & -0.12847 \\
\hline 34 & Flacourtia inermis Roxb. & 26 & 0.011781 & -4.44129 & -0.05232 \\
\hline 35 & Garcinia forbesii $\mathrm{L}$. & 1 & 0.000453 & -7.69939 & -0.00349 \\
\hline 36 & Melastoma affine D. Don & 6 & 0.002719 & -5.90763 & -0.01606 \\
\hline 37 & Amomum sp. & 152 & 0.068872 & -2.67551 & -0.18427 \\
\hline 38 & Garcinia parvifolia Miq. & 2 & 0.000906 & -7.00624 & -0.00635 \\
\hline 39 & Etlingera elatior (Jack) R. M. & 15 & 0.006797 & -4.99134 & -0.03392 \\
\hline 40 & Syzygium malacensis (L) Merr. & 29 & 0.01314 & -4.33209 & -0.05692 \\
\hline 41 & Alpinia siamensis K. Schum & 70 & 0.031717 & -3.45089 & -0.10945 \\
\hline 42 & Litsea garciae Vidal. & 36 & 0.016312 & -4.11587 & -0.06714 \\
\hline 43 & Macrosolen cochinchinensis (Lour.) Van & 18 & 0.008156 & -4.80902 & -0.03922 \\
\hline 44 & Borrassodendron borneensis & 21 & 0.009515 & -4.65487 & -0.04429 \\
\hline 45 & Lepisanthes amoena (Hassk.) Leenh. & 5 & 0.002266 & -6.08995 & -0.0138 \\
\hline 46 & Solanum ferox $\mathrm{L}$. & 4 & 0.001812 & -6.3131 & -0.01144 \\
\hline 47 & Muntinga calabura $\mathrm{L}$. & 67 & 0.030358 & -3.4947 & -0.10609 \\
\hline 48 & Morinda citrifolia $\mathrm{L}$. & 39 & 0.017671 & -4.03583 & -0.07132 \\
\hline No & Nama Ilmiah & $\begin{array}{c}\text { Jumlah } \\
\text { individu }\end{array}$ & $\mathbf{P i}$ & Ln Pi & $\mathbf{H}^{\prime}$ \\
\hline 49 & Passiflora foetida Linn. & 15 & 0.006797 & -4.99134 & -0.03392 \\
\hline 50 & Physalis angulata $\mathrm{L}$. & 67 & 0.030358 & -3.4947 & -0.10609 \\
\hline 51 & Sonneratia caseolaris L. & 51 & 0.023108 & -3.76756 & -0.08706 \\
\hline 52 & Mangifera odorata Griff. & 99 & 0.044857 & -3.10427 & -0.13925 \\
\hline \multirow{2}{*}{\multicolumn{2}{|c|}{$\begin{array}{l}\text { Total Individu } \\
\text { Indeks Keanekaragaman Jenis (H') }\end{array}$}} & 2.207 & & & -3.49484 \\
\hline & & & & & 3.49484 \\
\hline
\end{tabular}




\section{Kesimpulan}

Berdasarkan hasil penelitian yang telah dilakukan mengenai etnobotani buah edibel pada masyarakat Dayak Tahol di Kabupaten Malinau, maka dapat di ambil kesimpulan sebagai berikut:

1. Keanekaragaman jenis tumbuhan buah edibel yang diketahui pada masyarakat Dayak Tahol di Malinau sebanyak 52 jenis dari 25 famili. Indeks keanekaragaman sebesar 3,49 maka dari hasil tersebut tergolong dalam keanekaragaman tinggi H'> 3 .

2. Masyarakat Dayak Tahol memiliki kearifan dalam memanfaatkan jenis tumbuhan buah edibel sebagai bahan pangan, antara lain: diolah dengan cara dirujak (dipuncok), di olah dengan cara direbus dan digoreng, di rendam didalam air sungai yang mengalir, sebagai lalapan campuran nasi, sebagai bumbu asam ikan dan sayur, untuk obat luka dan untuk survival dalam hutan.

\section{Daftar Pustaka}

Afrianti, U.R. 2007. Kajian etnobotani dan aspek konservasi sengkubak (Pycnarrhena cauliflora (Miers.) Diels.) di Kabupaten Sintang Kalimantan Barat [tesis]. Bogor: Sekolah Pascasarjana IPB.

Ayu, FAP. 2012. Etnobotani Pangan Masyarakat Suku Dayak Kenyah Disekitar Taman Nasional Kayan Mentarang Kalimantan Timur. Bogor: Departemen Konservasi Sumber Daya Hutan dan Ekowisata Fakultas Kehutanan Institut Pertanian.

BPS."Kabuapten Malinau Dalam Angka Tahun 2016". Luas Wilayah, Proyeksi Penduduk, dan Kepadatan Menurut Kecamatan di Kabupaten Malinau. Badan Pusat Statistik Kabupaten Malinau. Kalimantan Utara 2016.

Fakhrurrozi, Y. 2001. Tumbuhan Buahbuah Liar Edibel (BLE) dan
Pemanfaatannya dalam Kehidupan Masyarakat Melayu Belitung. [Tesis].

Keraf, A.S. 2005. Etika Lingkungan. Jakarta: Penerbit Buku Kompas.

Supriati, R, dan Kasrina. 2003. Studi Etnobotani Tapak Dara (Catharanthus) dan Kerabat-kerabatnya Sebagai Tumbuhan Obat Pada Berbagai Golongan Etnis Di Kota Bengkulu. Makalah Seminar Nasional PPD 2002 Forum HEDS (34 September 2003. Medan).

Usat Y, M Hendra dan N Hariani. 2016. Studi Etnomedisin Satwa Pada Masyarakat Dayak Kenyah Lepoq Tukung Di Desa Batu Majang Kab. Mahakam Ulu. Prosiding Seminar Sains dan Teknologi FMIPA Unmul 2016, Samarinda.

Verheij, E.W.M and R.E. Coronel (eds.). 1991. Edible Fruits and Nuts. Netherland: Pudoc Wageningen. Plant Resources of South-East Asia (PROSEA). 